\title{
Inovasi Sistem Manajemen Administrasi Kependudukan Warga Berbasis Infomasi Elektronik Pada Aplikasi Pelayanan Dinas Kependudukan dan Pencatatan Sipil DKI Jakarta
}

\author{
Iqbal Aidar Idrus ${ }^{1 *}$, Ummi Zakiyah ${ }^{2}$ \\ ${ }^{1}$ Jurusan Ilmu Administrasi Publik, Universitas 17 Agustus 1045 Jakarta, 14350, Jakarta-Indonesia \\ ${ }^{2}$ Jurusan Ilmu Pemerintahan, Universitas 17 Agustus 1045 Jakarta, 14350, Jakarta-Indonesia
}

\begin{tabular}{l} 
Info Artikel \\
Dikirim: 10 Nov, 2021 \\
Diterima: 20 Jan, 2022 \\
Dipublikasi: 31 Jan, 2022 \\
\hline Kata Kunci: \\
Aplikasi; Informasi; Inovasi; \\
Pelayanan Publik \\
\hline
\end{tabular}

Koresponden:

Iqbal Aidar Idrus

Jurusan Ilmu Administrasi Publik, Universitas 17 Agustus 1945 Jakarta, 14350, JakartaIndonesia

Email:

iqbal.aidar@uta45jakarta.ac.id

Sitasi Cantuman:

Idrus, I. A. \& Zakiyah, U. (2022). Inovasi Sistem Manajemen Administrasi Kependudukan Warga Berbasis Infomasi Elektronik Pada Aplikasi Pelayanan Dinas Kependudukan dan Pencatatan Sipil DKI Jakarta. Journal of Political Issues. 3(2); 77-85. https://doi.org/10.33019/jpi.v3i 2.69

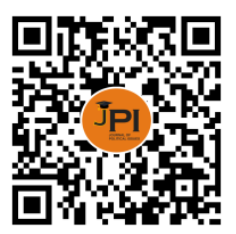

DOI:

https://doi.org/10.33019/jpi.v3i $\underline{2.69}$

Lisensi:

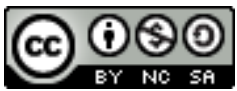

Attribution-NonCommercialShareAlike 4.0 International (CC- BY-NC-SA 4.0)

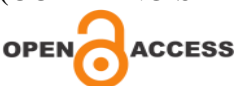

\begin{abstract}
ABSTRAK
Abstract The Provincial Government of DKI Jakarta provides the application of the Electronic Information-Based Population Administration Management System (Si Mas Gesit) to make it easier for the public to obtain the necessary information about the management of the population administration. As for this research aims to; 1) Identify the provision of public service information in the innovation of local government in the form of website applications and 2) Analyze how to optimize the application utilization of The Administrative Management System of Population Based Electronic Information (Si Mas Nimble). The research method used is qualitative. The analytical techniques used are qualitatively descriptive. The results showed that si Mas Gesit application there are six services that can be submitted by the community. Among others, the management of KTPEl, Kertu Child Identity (KIA), Family Card (KK), Moving In DKI, Moving Come Outside DKI, and Moving Come In DKI. And this application has mail governance features, daily service archive information at the village service counter that is managed and stored digitally with barcode security system. Utilization of Si Mas Nimble Application through system monitoring shows good utilization. In addition, it is necessary to optimize the utilization of applications by the public at large. The strategy of introduction and socialization of Si Mas Gesit Application is necessary and developed to facilitate the community in obtaining its population documents digitally.
\end{abstract}

Abstrak Penelitian ini bertujuan untuk mengetahui fungsi Sistem Manajemen Administrasi Kependudukan Berbasis Informasi Elektronik ( $\mathrm{Si}$ Mas Gesit) untuk mempermudah masyarakat dalam memperoleh informasi tentang persyaratan yang diperlukan terkait dengan pengelolaan administrasi kependudukan. Penelitian ini bertujuan untuk mengidentifikasi penyampaian informasi pelayanan publik dalam inovasi pemerintah daerah dalam bentuk aplikasi web dan menganalisis bagaimana mengoptimalkan penggunaan sistem manajemen administrasi berbasis warga informasi elektronik (Si Mas Gesit). Metode penelitian yang digunakan adalah kualitatif. Hasil penelitian menunjukkan bahwa aplikasi Si Mas Gesit berisi enam layanan yang dapat diberikan oleh masyarakat. Diantaranya pengurusan kartu tanda penduduk, kartu tanda pengenal anak (KIA), kartu keluarga (KK), perjalanan dalam DKI, perjalanan luar DKI, dan perjalanan dalam DKI. Aplikasi ini memiliki fitur manajemen surat menyurat, informasi catatan layanan harian di loket layanan desa dikelola secara digital dan disimpan menggunakan sistem keamanan barcode. Penggunaan aplikasi Si Mas Gesit melalui sistem monitoring menunjukkan efisiensi penggunaan yang baik. Selain itu, perlu dilakukan optimalisasi penggunaan aplikasi oleh masyarakat umum. Pengenalan dan sosialisasi aplikasi Si Mas Gesit diperlukan dan dikembangkan untuk memudahkan masyarakat dalam memperoleh izin tinggal digital.

\section{Tentang:}

Iqbal Aidar Idrus, menyelesaikan studi S2 Ilmu Pemerintahan, Universitas Muhammadiyah Yogyakarta pada tahun 2016. Penulis juga sedang menempuh studi S3 di Universitas Brawijaya. Saat ini penulis merupakan dosen tetap di Jurusan Ilmu Administrasi Publik Universitas 17 Agustus 1945 Jakarta.

Ummi Zakiyah, menyelesaikan studi S2 Ilmu Pemerintahan, Universitas Muhammadiyah Yogyakarta pada tahun 2016. Saat ini penlusi merupakan dosen di Jurusan Ilmu Pemerintahan, Universitas 17 Agustus 1945 Jakarta. 


\section{PENDAHULUAN}

Pada dasarnya setiap manusia memutuhkan pelayanan ahkan dapat dikatakan pelayanan tidak dapat dipisahkan dari kehidupan manusia. UU Pelayanan Publik no 25 Tahun 2009 dimaksudkan untuk memberikan kepastian hukum baik bagi masyarakat maupun penyelenggara pelayanan kepada masyarakat. Undang-Undang tersebut mengatur bahwa pelayanan publik merupakan perwujudan hubungan yang jelas mengenai hak tanggung jawab, kewajiban dan wewenang para pihak yang terkait dalam penyelenggaraan pelayanan publik. Mewujudkan sistem penyelenggaraan pelayanan pulik sesuai dengan peraturan umum. asas usaha dan pemerintahan yang baik penyelenggaraan pelayanan seagaimana yang dipersyaratkan undang-undang serta perlindungan dan kepastian hukum masyarakat dalam penyelenggaraan pelayanan pulik.

Pelayanan pulik adalah ukuran kinerja pemerintah yang paling terlihat. Publik dapat langsung menilai kinerja pemerintah berdasarkan pelayanan yang mereka terima. Untuk itu kualitas pelayanan pulik di seluruh kementerian lembaga menjadi isu mendasar yang perlu segera ditingkatkan (Kurniawan, 2017). Untuk menyikapi peningkatan pelayanan publik Kementerian Pendayagunaan Aparatur Negara dan Reformasi Birokrasi (KemenPAN RB) telah menerapkan kebijakan yang sejak tahun 2014 yang merupakan tahun inovasi pemerintah daerah dalam pelayanan publik. Semua instansi pemerintah baik pusat maupun daerah dapat memunculkan ide atau reaksi kreatif terhadap cara kerja metode pelayanan pulik.Hal ini dikarenakan masyarakat selalu menuntut pelayanan publik yang berkualitas baik dari pemerintah pusat maupun daerah. Meskipun kebutuhan tersbeut seringkali tidak sesuai dengan harapan karena dari pengalaman pelayanan publik yang muncul selama ini: kompleks,lamban, mahal dan mempersulit pelayanan (Menpan 2019).

Persyaratan inovasi pemerintah daerah secara jelas tertuang pada Undang-Undang 23 Tahun 2014 tentang Pemerintahan Daerah yang menyatakan bahwa dalam memuat kebijakan inovasi pemerintah daerah harus mengacu pada prinsip-prinsip, peningkatan efisiensi, meningkatkan kualitas,meningkatkan kualitas penyajian, tidak ada konflik kepentingan, terhadap kepentingan umum, dilakukan secara teruka; menjunjung tinggi nilai-nilai keenaran, dan dapat diartikan sebagai hasil ukan untuk dirinya sendiri. Inovasi kepegawaian bidang pelayanan kepada masyarakat merupakan kebutuhan yang diperlukan oleh Negara dan pemerintah daerah untuk mewujudkan pelaksanaan desentralisasi khususnya untuk meningkatkan kesejahteraan kemakmuran dan kemandirian masyarakat dan daerah. Tujuan inovasi pemerintah daerah adalah mempercepat pencapaian kesejahteraan masyarakat. Salah satu upaya untuk mencapainya melalui pelayanan publik. Wacana inovasi pelayanan publik saat ini memiliki implikasi penting bagi penyelenggaraan pelayanan pulik di Indonesia dimana kondisi perkembangan ilmu pengetahuan dan teknologi yang semakin maju dan persaingan global yang semakin ketat dan terbuka dalam kondisi sekarang (Gumilar, 2019).

Kemajuan teknologi informasi dan komunikasi (TIK) telah mengubah cara informasi disajikan dan memfasilitasi akses informasi. Pemanfaatan teknologi informasi dan komunikasi (TIK) di pemerintahan dapat meningkatkan operasional dan pengelolaan layanan berbasis TIK salah satunya adalah penerapan konsep e-government atau yang di kenal dengan digital government (Odendaal 2003). Di Indonesia pelaksanaan e-government tercapai setelah diterbitkannya Instruksi Presiden (Inpres) No. 3 Tahun 2003 tentang Kebijakan dan Strategi Nasional Pengemangan E-Government. Inpres ini dimaksudkan untuk menjadi dasar penyeimbang kedudukan pemerintah dalam penyelenggaraan sistem pemerintahannya untuk mewujudkan pemerintahan yang transparan akuntabel, efektif dan efisien serta peran serta masyarakat dalam pemerintahan. Penyampaian informasi berbasis TIK dapat terintegrasi dan difasilitasi oleh pengguna informasi sehingga pelayanan publik dapat lebih efisien dan efektif serta tepat sasaran khususnya pada masyarakat. 
Semua instansi pemerintah baik di pusat maupun daerah harus memunculkan ide atau tanggapan inovatif terhadap praktikmetode pelayanan publik. Namun pengelolaan kependudukan tersebut dinilai rumit terutama bagi warga yang bekerja di Jakarta khususnya yang berdomisili di Desa Cipedak Kecamatan Jagakarsa. Berawal dari keluhan masyarakat terutama yang bekerja jarak yang cukup jauh dan sering terjebak macet, dikarenakan untuk mengurusi administrasi ke dinas kependudukan minimal tiga kali pulang pergi ke kantor, sehingga warga harus mengambil cuti mendapat izin dan terkadang tidak masuk kantor untuk mengantar dokumen yang mereka inginkan harus selesai. Hal ini dikarenakan informasi persyaratan pengelolaan arsip kependudukan belum dilaksanakan secara optimal, ditambah belum adanya sarana komunikasi yang menghubungkan warga dengan aparat desa dan sebaliknya. Pentingnya arsip kependudukan sebagai kebutuhan dasar pengelolaan dokumen instansi lain oleh karena itu penyediaan arsip kependudukan harus sederhana dan cepat (Hadi, 2019).

Kelemahan lainnya adalah belum adanya sistem pengelolaan arsip dan korespondensi digital dimana surat dan arsip dapat dengan mudah ditemukan hal ini dikarenakan kurangnya ruang penyimpanan arsip konvensional. Sebagai kerahasiaan apabila terdapat permasalahan hukum mengenai keaslian isi surat pengakuan serta keamanan warga yang kehilangan kerusakan dokumen aslinya.Berdasarkan permasalahan terkait pelayanan kepada masyarakat banyak inovasi dan terobosan inovatif yang perlu dilakukan dalam pelaksanaan reformasi pemerintahan dengan menghadirkan penilaian terhadap upaya Pemprov DKI Jakarta dalam meningkatkan pelayanan publik organisasi, data kota dan pelaksanaan reformasi birokrasi dan inovasi di daerah (Sakti, 2019).

Namun penelitian ini mengkaji upaya Pemprov DKI Jakarta berinovasi melalui sistem manajemen administrasi kependudukan (Si Mas Gesit) berbasis informasi elektronik Kependudukan dan Catatan Sipil (Dukcapil) dalam mengidentifikasi penyampaian layanan publik inovasi pemerintah daerah dalam bentuk aplikasi website dan menganalisis bagaimana mengoptimalkan penggunaan sistem manajemen administrasi kependudukan berbasis TIK. Layanan Dukcapil dengan inovasi "Si Mas Gesit" telah menjadi salah satu penerima Penghargaan Kompetisi Inovasi Pelayanan Publik Terbaik 2019 dengan inovasi pemerintah daerah, BPBD telah membuat DKI Jakarta mendapatkan penghargaan tersebut.Sebelumnya inovasi ini dalam pelayanan tingkat kelurahan masih tersedia dan bersifat manual sehingga orang sering harus meluangkan waktu untuk mengelola dokumen manajemen kependudukan mereka. Dengan inovasi pelayanan yang leih baik diharapkan efisiensi operasional instansi dan hasil pelayanan kepada masyarakat menjadi leih baik.

\section{METODE PENELITIAN}

Penelitian ini dilakukan dengan menggunakan metode penelitian kualitatif. Penelitian kualitatif adalah tentang gagasan persepsi pendapat atau keyakinan orang dan tidak dapat diukur dengan angka. Teknik pengumpulan data dilakukan dengan kajian terhadap buku-uku referensi, laporan, jurnal dan media lain yang berhuungan dengan subjek penelitian.

\section{HASIL DAN PEMBAHASAN \\ Pelayanan Publik}

Pada Konsep pelayanan publik telah dikemukakan oleh banyak ahli. Bahkan dalam UU No. 25 Tahun 2009 definisi pelayanan pulik dinyatakan dengan jelas. Pelayanan publik mrupakan segala kegiatan dalam rangka pemenuhan kebutuhan dasar sesuai dengan hak-hak dasar semua warga negara dan penduduk atas suatu arang pelayanan atau pelayanan administrasi yang dierikan oleh penyelenggara pelayanan publik. Pelayanan juga merupakan kegiatan yang dilakukan oleh seseorang atau sekelompok orang dengan dasar tertentu yang tingkat kepuasannya hanya dapat dialami oleh pelayan atau yang dilayani tergantung pada 
kemampuan operator memberikan pelayanan untuk memenuhi harapan pengguna Moenir (2002). Pelayanan publik juga sebgai kegiatan atau rangkaian kegiatan dalam lingkup pemenuhan kebutuhan pelayanan sebagaimana ditentukan oleh undang-undang bagi setiap warga negara dan orang-orang atas barang jasa atau pelayanan administrasi yang disediakan oleh penyelenggara pelayanan publik khsusnya pada sebuah digital governance dalam memanfaatkan digitalisasi sebagai pelayanan yang cepat dan tetap dalam pengunaanya.

Definisi di atas memperjelas bahwa pelayanan publik merupakan proses pemenuhan kebutuhan melalui kegiatan orang lain untuk memantu mempersiapkan atau mengurus apa yang dibutuhkan orang lain. Dengan demikian pelayanan publik yang baik setidaknya harus memenuhi unsur-unsur kinerja pelayanan publik yang baik yaitu: sistem prosedur dan metode perilaku personel atau peralatan ketersediaan sarana dan prasarana serta respon masyarakat seagai pelanggan. Tercapainya faktor-faktor tersebut menentukan bagaimana suatu pelayanan publik menjadi pelayanan yang sejahtera.

Konsep penyelenggaraan pelayanan publik adalah suatu cara untuk meningkatkan kapasitas dan kemampuan pemerintah baik pusat maupun daerah dalam menjalankan fungsi pelayanan. Pemerintah berkewajiban memberikan pelayanan yang berkaitan dengan kebutuhan masyarakat seperti pelayanan kebutuhan dasar dalam hal ini pelayanan dibidang kesehatan dan bidang pendidikan dasar yang merupakan pelayanan dasar dan pelayanan publik pada administrasi barang dan jasa) (Hardiyansyah. 2011). Adapun jenis penyelenggaran pelayanan publik yang dikaji pada penelitian ini adalah jenis pelayanan umum yang bersifat administratif. Penyelenggaran pelayanan yang berfungsi untuk pemenuhan kebutuhan yang bersifat administrasi seperti: pemuatan KTP (Kartu Tanda Penduduk), akta kelahiran anak, Kartu Keluarga, Kartu Identitas anak (KIA), surat kematian, semua bentuk pelayanan yang bersifat administrative yang berhubungan dengan pemerintah daerah setempak baik kelurahan,kecamatan dan dinas terkait yang menangani pelayanan administrasi.

Kinerja pelayanan publik juga harus mengacu pada prinsip-prinsip dasar pelayanan publik sebagaimana Batinggi dan Ahmad (2013) menyatakan oleh karena itu dalam upaya peningkatan pelayanan perlu adanya disiplin antara penyedia layanan di sektor publik seperti:

a) Menetapkan standar pelayanan artinya standar tidak hanya berhuungan dengan standar pelayanan produk tetapi juga dengan standar prosedur pelayanan yang berkaitan dengan pemberian pelayanan yang berkualitas.

b) Bersikap terbuka terhadap kritik dan saran serta keluhan memberikan semua informasi yang diperlukan dalam layanan. Penyedia layanan publik harus memiliki berbagai sarana bagi masyarakat untuk menyampaikan keluhan kritik dan saran serta harus secara efektif menyampaikan dan beragai informasi yang diperlukan kepada komunitas klien.

c) Perlakukan semua orang dengan adil. Kata adil di sini berarti dengan memberikan sebagian barang tertentu dalam penyelenggara agar memiliki pilihan yang bersifat transparan.

d) Menjelaskan atau membenarkan sesuatu dalam proses pemberian pelayanan apabila terjadi penyimpangan terkait pemberian pelayanan maka setiap pegawai dillini pelayanan pada semua tingkatan, dari atasan sampai bawahan ketika mendeteksi penyimpangan harus segera melakukan konfirmasi atau klarifikasi sesuai dengan kemampuannya.

e) Memberikan kemudahan akses pelayanan bagi semua pelanggan pelayanan. Unit pelayanan yang telah disediakan pelayanan publik harus benar-benar dapat diakses.

f) Selalu memberikan pembaruan dan upaya untuk meningkatkan kualitas layanan 
Dalam hal ini penyedia layanan dan pelaksana layanan harus terus melakukan pembaruan dan perbaikan secara responsive, konsisten dengan kontriusi komunitas pelanggan dan evaluasi kinerja layanan serta proaktif pada manajemen.

\section{Inovasi Pemerintahan Daerah}

Inovasi dipahami sebagai upaya untuk menjadi sesuatu yang baru. Kemudian pendapat lain yang dikemukakan oleh Setyteringrum 2009 mendefinisikan inovasi sebagai suatu objek yang juga berarti suatu produk baru atau suatu tindakan yang tersedia untuk diadopsi dan harga produk tersebut berada di dunia usaha atau dalam konteks komersial. Penelitian sebelumnya membahas tentang inovasi di pemerintah daerah berfokus pada identifikasian pola perilaku dan cara di mana kepemimpinan politik administratif dan kepemimpinan dapat mendorong inovasi yang efektif dan sering dilakukan. Ada beberapa faktor yang mempengaruhi adopsi inovasi di tingkat lokal namun belum membahas hubungan antara staf dan pejabat terpilih atau kepemimpinan sebagai variabel independen seperti kajian Damanpour dan Schneider (2009), dimana pada kajian tersebut inovasi hanya berfokus pada beberapa indicator saja, sehingga inovasi harus menjadi pembedah dan sesuatu yang baru dari sebelumnya dalam hal ini ada peningkatan dalam memberikan pelayanan. Penelitian empiris ini membahas dua pertanyaan yang belum menjadi fokus utama penelitian inovasi seelumnya terutama berkenaan dengan pemerintah daerah.

Dalam hal ini kita bisa melihat beberapa penelitian terdahulu dimana Kimerly L. Nelson Curtis H. Wood dan Gerald T membahas mengenai Innovation Management in Local Government: An Empirisal Analysis of Suuran Cities mendefinisikan inovasi pemerintah daerah tidak hanya sebagai penemuan tetapi sebagai perubahan organisasi untuk meningkatkan kinerja. Beberapa kebijakan dan implementasi program didasarkan pada "praktik terbaik" yang khas dari pemerintah daerah yang berbeda. Selesai tetapi pemerintah kota jarang dapat meminjam ide tanpa modifikasi dalam hal ini harus di implemtasikan suatu ide baru atau inovasi bukan hanya sebagai sebuah rencana yang menjadi sebuah konsep saja. Inovasi memerlukan beberapa penyesuaian untuk memenuhi kebutuhan organisasi tertentu memenuhi aspek kebijakan dan mendukung pemangku semua kepentingan dalam hal ini kepentingan yang harus di penuhi yaitu kebutuhan masyarakat (Nelson, et.al, 2011) .

Inovasi memberikan sesuatu yang baru dan berbeda dalam kualitas dan kuantitas dari produk atau jasa yang sudah ada. Inovasi pelayanan publik dikatakan berhasil apabila merupakan hasil dari penciptaan dan penerapan inovasi produk dan jasa inovasi, proses pelayanan inovasi, metode pelayanan inovasi, kebijakan inovasi ,pelayanan publik sistem pelayanan (Mochammad, 2019). Pertama inovasi produk atau jasa adalah perubahan tampilan dan desain suatu produk atau jasa. Kedua inovasi prose meningkatan kualitas yang berkelanjutan dan mengacu pada komibnasi perubahan organisasi prosedur dan kebijakan yang diperlukan untuk berinovasi. Ketiga inovasi metode layanan adalah perubahan baru dalam cara berinteraksi dengan pengguna layanan. Keempat inovasi strategis atau kebijakan perubahan visi dan misi tujuan dan strategi serta alasan baru untuk menyimpang dari kenyataan yang ada. Kelima inovasi sistem adalah interaksi sistemik yang mencakup caracara aru atau yang dipengaruhi (Muluk,2008).

\section{Inovasi Pelayanan Penyediaan Informasi Dalam Aplikasi Si Mas Gesit}

Pemerintah Provinsi DKI Jakarta yang dipimpin oleh Suku Dinas Catatan Sipil dan Kependudukan (Dukcapil) melalui Satuan Pelayanan (Satpel) Kelurahan Cipedak melakukan inovasi pelayanan dengan memperkenalkan sistem pengelolaan administrasi kependudukan yang mengandalkan informasi elektronik ( $\mathrm{Si}$ Mas Gesit) untuk memudahkan masyarakat. Si Mas Gesit adalah aplikasi yang dirancang untuk memerikan pelayanan kepada masyarakat dalam bentuk elektronik. Aplikasi tersebut dirancang sesuai inovasi pemerintah daerah dalam bentuk website/aplikasi $\quad \mathrm{Si}$ Mas Gesit alamat 
http://simasgesit.kepenresidenancapil.jakarta.go.idcipedak, warga langsung mendapat informasi tentang persyaratan yang diperlukan. Manfaatnya adalah pengaturan administrasi yang dipersingkat penghematan waktu dan penghindaran praktik perantara (Pemkot Jakarta Selatan, 2019).

Dalam sistem aplikasi tersebut masyarakat dapat memberikan enam pelayanan yaitu mendapatkan Kartu Tanda Penduduk Kartu Tanda Penduduk (KIA), Kartu Keluarga (KK), Pindah ke DKI Pindah/ke Luar DKI dan Pindah Dalam DKI. Aplikasi Si Mas Gesit digunakan untuk meningkatkan kualitas pelayanan pemerintah kepada masyarakat kelurahan, meningkatkan transparansi pelayanan pengendalian dan akuntabilitas pemerintah di kelurahan. Inovasi ini juga memungkinkan untuk mengurangi hilangnya waktu serta biaya transportasi yang dikeluarkan orang untuk satu kali perjalanan pulang pergi untuk memastikan kelengkapan administrasi. Selanjutnya dalam pengelolaan dokumen digital disimpan melalui data digital harga bisa lebih aman. Penggunaan aplikasi komputer merupakan salah satu solusi cerdas untuk menghadapi dinamika perubahan di era digitalisai khsusunya pada system e-government.

Di situs tersebut fungsi pengelolaan surat informasi layanan harian yang disimpan di loket layanan desa dikelola secara digital dan disimpan menggunakan sistem keamanan arcode. Data arsip yang dapat diambil oleh petugas Klaim dapat diperiksa lebih cepat dan bertahap mulai dari staf hingga manajemen secara elektronik dan digital. Aplikasi Si Mas Gesit berpotensi dan memungkinkan untuk terhubung dengan wilayah kerja unit pelayanan di wilayah metropolitan DKI Jakarta, yang juga membutuhkan sistem yang sama dan kini direplikasi di lokasi yang berbeda. Karena aplikasi ini memecahkan masalah yang ada di perkotaan di seluruh DKI Jakarta dan penerapan ini berdampak mengurangi jumlah masyarakat yang pergi ke loket pelayanan desa apalagi kondisi pandemic saat sekarang ini, mengurangi terjadinya kerumuman dalam pelayanan tersebut. Dengan aplikasi ini sangat membantu pelayanan yang dimana dulunya mengantri untuk mengajukan permohonan kemudian kembali lagi untuk mengambilnya. namun kini masyarakat hanya datang sekali yaitu untuk mendapatkan yang diinginkan serta dapat menggunakan sumber daya di era modernisasi saat sekarang ini. Aplikasi Si Mas Gesit terus berkarya dan berkemang untuk memudahkan masyarakat mendapatkan izin tinggal dalam bentuk digital. Kecamatan yang telah mereplikasi program aplikasi Si Mas Gesit di Provinsi DKI Jakarta saat ini hanya Kecamatan Cipedak Kecamatan Jagakarsa Kota Jakarta Selatan (Pemkot Jakarta Selatan, 2019).

Implementasi inovasi pelayanan publik berasis Aplikasi tersebut secara umum akan berhasil memenuhi kriteria dan tolak ukur keerhasilan suatu inovasi. Pertama dalam hal inovasi produk atau jasa terjadi perubahan tampilan dan desain produk atau jasa. Aplikasi Si Mas Gesit merupakan produk layanan berasis aplikasi yang baru saja dibuat oleh Pemerintah DKI Jakarta dari manual lama dan konvensional beralih ke layanan digital dan berasis aplikasi yang memungkinkan proses dan interaksi layanan kapan saja di mana saja, hal tersebut juga di terapkan di mall pelayanan publik yang dimana semua bentuk pelayanan admiistratif tersedia di sana dan bisa langsung mengurusi semuanya dalam sekali kunjungan, dimana terdapat banya instansi pemerintahan dan lembaga lainya.

Kedua tentang kebaruan layanan aplikasi Si Mas Gesit ini adalah model layanan terbaru dengan sistem pengumpulan model yang dirancang hanya oleh pemerintah DKI Jakarta dan belum tersedia di lembaga negara. Namun hal ini harus menjadi model dalam upaya peningkatan kualitas pelayanan publik bagi masyarakat. Ketiga reformasi tersebut bersifat metodologis dengan sistem pick up and drop off artinya dulu ketika masyarakat membutuhkan pelayanan masyarakat harus datang ke meja pelayanan, namun sekarang berbeda dan inovasi-inovasi baru yang diberikan Pemprov DKI Jakarta kepada masyarakat. Keempat inovasi strategis atau kebijakan adalah perubahan visi misi tujuan dan strategi serta 
alasan baru untuk menyimpang dari kenyataan yang ada. Layanan aplikasi Si Mas Gesit yang diluncurkan termasuk sebuah inovasi baru bertujuan untuk memberikan informasi pelayanan publik, yang dirancang dalam inovasi pemerintah daerah berupa alamat aplikasi dan meningkatkan kualitas layanan pemerintah.

Kelima inovasi sistemik adalah interaksi sistemik yang mencakup cara-cara baru atau yang diperbarui dalam berinteraksi dengan aktor lain atau dengan kata lain perubahan tata kelola. Inovasi tersebut berpotensi dan memungkinkan untuk terhubung dengan wilayah kerja unit pelayanan di wilayah metropolitan DKI Jakarta yang juga memutuhkan sistem yang sama dan kini direplikasi di lokasi yang berbeda di wilayah DKI Jakarta. Karena aplikasi ini memecahkan masalah yang ada di perkotaan di seluruh DKI Jakarta, penerapan ini berdampak mengurangi keutuhan masyarakat untuk pergi ke loket pelayanan yang dulunya mengantri untuk menyerahkan dokumen kemudian kembali lagi untuk mengambilnya sehingaa mempermudah masyarakat dalam menikmati pelayanan dalam era digitalisasi government dalam hal ini pelayanan publik berbasis aplikasi yang sangat membantu dan mempermudah proses pengurusan administrative di pemerintahan.

\section{SIMPULAN}

Pengelolaan kependudukan dinilai rumit terutama bagi penduduk yang bekerja di Jakarta,Mereka mengeluh bahwa mereka harus melakukan setidaknya tiga kali perjalanan di sekitar kantor lurah sampai mereka menyelesaikan dokumen yang mereka inginkan. Sistem Manajemen Administrasi Kependudukan Penduduk Berasis Informasi Elektronik atau Si Mas Gesit ini dibuat oleh Suku Dinas Kependudukan dan Kedudukan Sipil (DUKCAPIL). Inovasi ini hadir untuk mempermudah pengiriman dokumen kependudukan. Sebelum adanya inovasi ini pelayanan di tingkat kelurahan masih bersifat manual sehingga untuk mengurus mengurus dokumen kependudukan seringkali masyarakat membutuhkan waktu lama untuk kembali dan seterusnya. Hal tersebut dijawab oleh Suku Dinas Kependudukan dan Pencatatan Sipil (DUKCAPIL), dengan program inovasi Si Mas Gesit Masyarakat DKI Jakarta khusunya dalam mengurus Administrasi kependudukan tidak terlalu bertele-tele lagi dan tanpa harus bolakalik ke kelurahan dan menghaiskan waktu dalam pengurusannya. Hal ini cukup di lakukan melalui Aplikasi Si Mas Gesit melalui perangkat elektronik dengan menyiapkan persyaratan yang diperlukan dan hanya datang ke kelurahan jika sudah jadi dan tinggal mengambilnya, akan tetapi sayangnya program tersebut belum semuanya di terapkan di seluruh wilayah kelurahan yang ada di DKI Jakarta untuk kemudahan pelayanan dala mengurus administrasi kependudukan alhasil program tersebut sukses dilaksanakan oleh beberapa Kelurahan DKI Jakarta yang dapat mengoptimalkan dalam pelayanan serta data tersebut dapat di arsipkan dan mudah di cari jika suatu saat diperlukan dalam kepengurususan administrasi kependudukan.

Untuk program tersebut penulis menyarankan agar program "Si Mas Gesit" agar segera di replikasikan/digunakan di semua wilayah atau semua kelurahan yang ada di DKI Jakarta, hal ini dengan tujuan agar pelayanan inovasi dapat berjalan merata serta dapat memudahkan semua masyarakat DKI Jakarta dalam pengurusan administrasinya tanpa pelu bolak-balik dan ribet dalam mengurus dokumen yang penting bagi pribadi setiap warga dalam bernegara. Penulis juga memberikan saran agar provinsi/daerah lain dapat mencontoh apa yang dilakukan pemerintah provinsi Dki Jakarta melalui Satuan Pelayanan Kelurahan Cipedak dalam berinovasi pelayanan public sehingga membuat pemerintah daerah semakin berkembang dan maju.

\section{DAFTAR PUSTAKA}

Batinggi, A dan Badu Ahmad. (2013). Manajemen Pelayanan Publik. Yogyakarta: Andi Offset 
Damanpour, F., \& Schneider, M. (2008). Characteristics of Innovation and Innovation Adoption in Public Organizations: Assessing the Role of Managers. Journal of Public Administration Research and Theory, 19(3), 495-522. https://doi.org/10.1093/jopart/mun021

Gumilar, M. G. (2019). Inovasi Pemerintah Daerah Jogja Smart Service Dalam Menciptakan Smart And Liveable City Di Kota Yogyakarta. Jurnal Gama Societa, 3(1), 19-27. Doi: https://doi.org/10.22146/jgs.50012.

Hadi, F. (2019). Satpel Dukcapil Cipedak Bikin Terobosan Pelayanan Kependudukan Bernama $\mathrm{Si}$ Mas Gesit. Retrieved from wartakota.tribunnews.com:

https://wartakota.tribunnews.com/2019/07/01/satpel-dukcapil-cipedakbikin-terobosan-pelayanan-kependudukan-bernama-si-mas-gesit (Diakses tanggal 5 November 2020)

Hardiyansyah. 2011. Kualitas Pelayanan Publik Konsep, Dimensi, Indikator dan. Implementasinya. Yogyakarta : Gava Media

Nelson, K. L., Wood, C. H., \& Gabris, G. T. (2011). Innovation management in local government: an empirical analysis of suburban municipalities. International Journal of Organization Theory \& Behavior, 14(3), 301328. https://doi.org/10.1108/ijotb-14-03-2011-b001

Kurniawan, R. C. (2017). Inovasi Kualitas Pelayanan Publik Pemerintah Daerah. Fiat Justisia:Jurnal Ilmu Hukum, 10(3). https://doi.org/10.25041/fiatjustisia.v10no3.794.

Menpan. (2019). Si Mas Gesit Bantu Warga Cipedak Urus Administrasi. Retrieved from menpan.go.id: https://www.menpan.go.id/site/berita-terkini/si-mas-gesit-bantuwarga-cipedak-urus-administrasi (Diakses tanggal 5 November 2020)

Mochammad, R. (2019). Inovasi Pelayanan Publik. KEMUDI : Jurnal Ilmu Pemerintahan, 4(1), 1-20. Retrieved from https://ojs.umrah.ac.id/index.php/kemudi/article/view/1335

Moenir. 2006. Manajemen Pelayanan Umum di Indonesia, Bumi Askara, Jakarta.

Muluk, K. (2008). Knowledge Management: Kunci Sukses Inovasi Pemerintahan Daerah. Malang: Bayumedia.

Odendaal, N. (2003). Information and communication technology and local governance: understanding the difference between cities in developed and emerging economies. Computers, Environment and Urban Systems, 27(6), 585-607. https://doi.org/10.1016/s0198-9715(03)00016-4

Pemkot Jakarta Selatan. (2019). Si Mas Gesit Dukcapil Cipedak Mudahkan Warga Urus Dokumen Kependudukan. Retrieved from selatan.jakarta.go.id: https://selatan.jakarta.go.id/news/2019/07/si-masgesit-dukcapil-cipedak-mudahkan-warga-urus-dokumenkependudukan\#: :text=Suku\%20Dinas\%20Kependudukan\%20dan\%20Pe ncatatan,dokumen $\% 20 \% 20$ kependudukan $\% 20$ bagi $\% 20$ warga $\% 20$ Kelurah 

an (Diakses 5 November 2020)

Sakti, B. (2019). Kompetensi aparatur pemerintah daerah dalam era reformasi. Pareto : Jurnal Ekonomi Dan Kebijakan Publik, 2(1), 35. https://doi.org/10.32663/pareto.v2i1.917 